\title{
"FOR THE UNITED STATES": GOVERNMENT LAWYERS IN COURT
}

\author{
PATRICIA M. WALD* \\ 1 \\ INTRODUCTION
}

It is a rare attorney practicing in the federal courts who does not encounter government lawyers on a regular basis. ${ }^{1}$ Those of us on the bench-particularly those of us in the D.C. Circuit-have had many opportunities to become familiar with government lawyers. In my nineteen-plus years as a federal appellate judge, I have engaged with hundreds-perhaps thousands- of government lawyers as they argue their way through the approximately eighty-three percent of our docket in which the federal government is a party. ${ }^{2}$ Before becoming a judge, I did two stints in the D epartment of J ustice ("DO J"), the second time as an A ssistant A ttorney General for Legislative A ffairs. A Ithough I functioned in that job primarily as a legislative advocate for D OJ before Congress, I often discussed the Department's positions on pending bills with lawyers both within DOJ and within other departments and independent agencies. In my private practice, I worked both alongside and in opposition to government attorneys. Like eight of my ten colleagues on the D.C. Circuit, I have "been there," and from my "here now" vantage point as a judge, I propose to set down, largely impressionistically, some of my observations and reactions to government lawyering in court.

II

\section{The Government LA WYER And THE COURT}

In the tripartite system of government our Constitution establishes, the relationship between judges and government lawyers is, ideally, conducted at arm's length. In a very basic sense, we are part of the same government, but our residence in two separate branches is designed, in part, to ensure that the courts function as the bulwark of citizens' liberties, standing fast against a po-

Copyright $\odot 1998$ by L aw and Contemporary Problems

This essay is also available at http://www.law.duke.edu/journals/61L C PWald.

* J udge, U nited States C ourt of A ppeals for the D istrict of Columbia Circuit; Chief J udge, 19861991. A ssistant A ttorney G eneral, O ffice of L egislative A ffairs, D epartment of J ustice, 1977-79.

The author would like to thank her law clerk Laura H eymann, J.D. 1997, U niversity of California at B erkeley School of $L$ aw (B oalt $H$ all), for her assistance on this essay.

1. By "government lawyer," I am referring to lawyers who represent the federal, rather than a state, government.

2. SeeUnited States Courts, District of Columbia Circuit, 1995 A nnual Report 41. 
tentially tyrannical or overbearing government eager to encroach on citizens' legal rights. Indeed, one of the distinctive aspects of our A merican system of justice that reformers seek to export abroad is the court's independence not only from the executive and legislative branches in general but more specifically from the prosecutor who brings cases to the court on behalf of the state. In Eastern E urope, where I have worked over the past seven years with newly emerging democracies intent on making their judges "independent" protectors of human rights and constitutional integrity, one of the most vexing dilemmas facing reformers is how to convert the formerly all-powerful Procurator (prosecutor) into just another lawyer. U nder prior socialist regimes, the Procurator was part of the court system: $\mathrm{He}$ sat on the bench, robed, alongside the judges and had extensive powers to arrest, detain, and interrogate those suspected of violating the criminal law. During his investigations he consulted with the judges ex parte. In these countries, including Czechoslovakia, R omania, and Bulgaria, he was by far the most powerful and prestigious person in the courtroom, and his strong party connections made him the one to see for results, or, perhaps, for mercy. $H$ is powers were equally extensive in the civil courts, where he could intervene in suits between private parties as the "protector of the law." ${ }^{3}$ In light of the systems that existed in these countries, it is a significant achievement that A merican judges must treat government lawyers like anyone else in the courtroom. ${ }^{4}$

$Y$ et our A merican model of complete independence is often belied by the reality of daily experience. N ot only do we see government lawyers generally, and many individual ones as well, far more often in court than we see private lawyers, but also a disproportionate number of federal judges have been drawn from the ranks of government lawyers. E ight of our eleven active D.C. Circuit appeals judges, for example, have been D OJ lawyers or A ssistant U.S. A ttorneys at one time or another in their careers. This statistic can, of course, cut both ways: While DOJ or agency alumni may have a special understanding of how policy positions are formulated and litigating strategies are adopted within the government, they will also feel more at liberty to second-guess those decisions. Witness, for example, a recent statement by one of our judges, who reluctantly concurred in the court's decision to uphold a criminal conviction: "A s a J ustice D epartment alumnus, I simply cannot imagine approving, had it come to me, the prosecution of Bryant, who seems to be an unfortunate scapegoat."

3. Seeharold J. Berman, J UStice In THE U.S.S.R. 238 (1963); Stephen C. Thaman, Reform of the Procuracy and Bar in Russia, 3 PARKER SCH. J. E. E UR. L. 1 (1996).

4. See, e.g., Judicial Conference of the United States, Code of Conduct for United STATES JUDGES Canon 3A (4) (1997) (instructing federal judges neither to "initiate nor consider ex parte communications ... [concerning] a pending or impending proceeding").

5. U nited States v. B ryant, 117 F.3d 1464, 1472 (D.C. Cir. 1997) (Silberman, J., concurring), cert. denied, 118 S. Ct. 1510 (1998); see also Summers v. D epartment of J ustice, 140 F.3d 1077, 1084 (D.C. Cir. 1998) (Silberman, J., concurring) ("I find myself in a rather strange situation in this case because, unlike the district judge, I have in a sense reviewed Hoover's official and confidential files 'in camera,' but did so almost 25 years ago as the D eputy A ttorney G eneral (and A cting A ttorney General) of the U nited States."). 
In my own case, a stint as D O J's legislative liaison taught me that the policy rationales offered as the government's position by a "mission-oriented" agency may differ from the ones that would result if the White $\mathrm{H}$ ouse and $\mathrm{O}$ ffice of $M$ anagement and Budget ("OM B") were consulted-a lesson that resonates from time to time in my judicial work. ${ }^{6}$ Familiarity may not breed contempt, but it may subtly dilute deference.

The relationship between judges and government lawyers is forged as much by our current mentoring efforts as by our past experiences. A healthy percentage of D.C. Circuit law clerks, for example, go on to work as government lawyers. A Ithough a judge will not sit on any cases in which a former clerk appears as counsel for two years after the clerkship, and clerks, in turn, cannot be involved in any cases that were in the appeals court during their tenure, like proud parents we keep abreast of our clerks' progress and share court and D OJ small talk with them. In addition, some of us participate in A dvocacy Institutes, which train government lawyers from around the country, and in our circuit, government lawyers make up a healthy segment of invitees to the J udicial Conference, where judges and lawyers build relationships in the course of discussing common concerns. Finally, when judges are sued in their official capacity (and it happens, not frequently but intermittently), they are usually defended by government lawyers. ${ }^{8}$ There are, in sum, institutional connections between federal judges and government lawyers that need not and do not impugn our partiality but rather emphasize our involvement in a common public service enterprise. ${ }^{9}$

It is because judges often see themselves in something of a supervisory role in this enterprise ${ }^{10}$ that they are wont to say often and loudly that they expect a

6. See, e.g., Sierra Club v. Costle, 657 F.2d 298, 406 (D.C. Cir. 1981) (footnotes omitted): The authority of the President to control and supervise executive policymaking is derived from the Constitution; the desirability of such control is demonstrable from the practical realities of administrative rulemaking. R egulations such as those involved here demand a careful weighing of cost, environmental, and energy considerations. They also have broad implications for national economic policy. Our form of government simply could not function effectively or rationally if key executive policymakers were isolated from each other and from the Chief Executive. Single mission agencies do not always have the answers to complex regulatory problems. A n overworked administrator exposed on a 24-hour basis to a dedicated but zealous staff needs to know the arguments and ideas of policymakers in other agencies as well as in the W hite $\mathrm{H}$ ouse.

7. U nder the Code of J udicial Conduct, as currently interpreted, judges may not attend and speak at "brown bag" lunches at a private firm, although they may speak at bar functions. See COMMITTEE ON CODES OF CONDUCT, COMPENDIUM OF SELECTED OPINIONS $\S \S 4.5,4.6(i)$ (1995).

8. See, e.g., J ones v. G asch, 404 F.2d 1231 (D.C. Cir. 1967); J A MES EISENSTEIN, COUNSEL FOR THE UNITED STA TES 131 (1978).

9. D ouglas $L$ etter makes this point in L awyering and J udging on B ehalf of the U nited States: All I A sk for is a Little Respect, 61 GE O. W A SH. L. R EV . 1295, 1296 (1993) (“I am not just a 'lawyer.' I am a public servant who works in court.").

10. See, e.g., EISENSTEIN, supra note 8, at 145 (quoting one judge as saying, "The U .S. attorney ... represents the government, which means everybody and nobody. There is no one there so directly concerned to watch like a client would. So it's partially my responsibility to see that the government attorney does a good job."). 
"higher standard" from a government lawyer, ${ }^{11}$ even as they acknowledge elsewhere that a great deal of the work government lawyers do is little different from that of their counterparts in the private sector. ${ }^{12}$ Part, if not all, of this expectation results from the fact that the government lawyer's client is seen as being not simply the individual whose particular fate is being litigated but also the U.S. citizenry at large, a client whose ultimate objective is that justice be done. ${ }^{13}$ A s one member of the profession writes, because government lawyers are "public servant[s]," they should be held to "extremely high standards of ethics, morality, and responsibility." ${ }^{14}$ These standards manifest themselves in ways that might be seen as antithetical to the lawyer's role in private practice; a government lawyer may feel obliged to alert an opposing lawyer about a technical defect in her papers that might result in her case being dismissed before it gets to the merits or will "act in litigation in ways that seem to be against the narrow interest of the client in a particular case but may be of overall benefit to society." ${ }^{15}$ The commentary to the A merican B ar A ssociation's M odel Code of Professional Conduct also sounds a public-minded note, stating that "[a] prosecutor has the responsibility of a minister of justice and not simply that of an advocate." 16

11. See, e.g., A ssociation of A m. Physicians \& Surgeons, Inc. v. Clinton, 989 F. Supp. 8, 16 (D .D .C. 1997) (noting that D OJ "has a long tradition of setting the highest standards of conduct for all lawyers").

12. See, e.g., Etelson v. Office of Personnel Mgt., 684 F.2d 918, 927 (D.C. Cir. 1982) (" $[G$ ]overnment and private litigators are simply lawyers on opposite sides of any given legal action. O ne generally attacks agency action; the other generally defends it against the selfsame attacks. The legal skills acquired in these pursuits are identical.").

13. See Berger v. U nited States, 295 U.S. 78, 88 (1935), overruled on other grounds, Stirone v. U nited States, 361 U.S. 212 (1960):

The U nited States A ttorney is the representative not of an ordinary party to a controversy, but of a sovereignty whose obligation to govern impartially is as compelling as its obligation to govern at all; and whose interest, therefore, in a criminal prosecution is not that it shall win a case, but that justice shall be done.

See also In re Bruce R. Lindsey (Grand Jury Testimony), 148 F.3d 1100, 1108 (D.C. Cir. 1998) ("U nlike a private practitioner, the loyalties of a government lawyer . . . cannot and must not lie solely with his or her client agency."). B ut see Catherine J. Lanctot, The D uty of Z ealous A dvocacy and the E thics of the Federal G overnment L awyer: The Three H ardest Q uestions, 64 S. CA L. L. REV . 951, 955 (1991) ("G overnment lawyers, for the most part, perceive their role as that of zealous advocates for their agency clients, just like other lawyers representing private clients." ); G eoffrey P. M iller, G overnment L awyers' E thics in a System of Checks and Balances, 54 U . CHI. L. R E V. 1293, 1294-95 (1987) ("D espite its surface plausibility, the notion that government attorneys represent some transcendental 'public interest' is, I believe, incoherent. It is commonplace that there are as many ideas of the 'public interest' as there are people who think about the subject.").

14. L etter, supra note 9 , at 1296 .

15. Id. at 1299. Such behavior is perhaps in deference to the inscription on the wall next to the A ttorney G eneral's office: "The U nited States wins its point whenever justice is done its citizens in the courts."

16. Model Rules of Professional ConduCt Rule $3.8 \mathrm{cmt}$. (1983); see also M Odel COde OF PROFESSIONA L RESPONSIBILITY EC 7-14 (1981) ("A government lawyer in a civil action ... has the responsibility to seek justice and to develop a full and fair record, and he should not use his position or the economic power of the government to harass parties or to bring about unjust settlements or results."). 
R arely, however, do judges describe the "higher standard" of conduct necessary to ensure justice, although it is almost always apparent when judges feel their expectations have not been met (in other words, "I know it when I don't see it"). In my experience, judges in my circuit tend to get most irritated when they think a government lawyer has fallen short in a criminal case, where someone's life or liberty is pitted against the public's safety and welfare. In a 1992 drug case, for example, the court chastised government counsel for failing to disclose fingerprint evidence until the eve of trial and for handing one of the police witnesses-in full sight of the jury-a set of keys also previously undisclosed to the defendant. ${ }^{17}$ The court, which ordered a new trial on other grounds, went out of its way to ensure that the government lawyer would play by the rules in the next round:

We are confident that the government will take proper measures to ensure that both the fingerprints and the keys will be properly disclosed to [the defendant] in advance of trial. We do, however, note the less than professional way in which the government tried this case and reprove the government for it.

In another case, decided three months earlier, the court felt compelled to "express its concern" about the government's tactics on appeal, pointing to five "material misstatements of the record" in the government's brief and noting:

A lawyer appearing before us has a duty to assert facts only if, after a reasonably diligent inquiry, he believes those facts to be true. ... That the Government made these misstatements renders the conduct here even more egregious. ... This court condemns unprofessional conduct by the Government whether it results from incompetence or manipulation.

A nd in 1969, the court lamented the lack of control of a prosecutor who told the jury in his closing argument in a first-degree murder case that the defendant "waited for her there with his gun, and shot her, stabbed her, and kicked her - shot her down just like a dog." ${ }^{20}$ Though not willing to reverse the conviction, the judge delivered the following sermon against the excesses of prosecutorial zeal:

The test of reversal is not the only test of appropriate conduct. The prosecutor may "strike hard blows," but not "foul." We need not characterize the prosecution argument here as foul to conclude that the prosecution has an obligation to set an example of professional conduct. The Government may prosecute vigorously, zealously with hard blows if the facts warrant, for a criminal trial is not a minuet. N evertheless, there are standards which a Government counsel should meet to uphold the dignity of the Government. The language of the prosecutor here was hardly in keeping with what the Courts and the public expect of its representatives. We take this occasion to remind the bar, prosecutors and defense counsel alike, that we expect-indeed insistthat their conduct reflect that they are officers of the court as well as advocates for a cause.

\footnotetext{
17. See U nited States v. Patrick, 959 F.2d 991 (D.C. Cir. 1992).

18. Id. at 995 n.5.

19. U nited States v. W illiams, 952 F.2d 418, 421-22 (D.C. Cir. 1991).

20. Taylor v. U nited States, 413 F.2d 1095, 1096 (D.C. Cir. 1969) (citation omitted).

21. Id.
} 
In each of these three cases, the government attorney was found to have committed an ethical or professional breach, but the reason underlying the court's disapproval seems to be slightly different in each situation. In the fingerprint case, the court's concern seemed to be rooted in the inherent advantage the government has over a defendant in a criminal trial; the failure to disclose evidence in a timely fashion upsets the level playing field that the courts have attempted to create. ${ }^{22}$ In the material misstatements case, the government attorney violated norms applicable to all lawyers but was chastised for failing to meet a higher standard of conduct because she represented the government. A nd in the closing arguments case, the focus of the court's reprimand was on the special position prosecutors hold as representative of the people. None of the three cases gives us any clear sense of what "higher standard" means in courtroom practice beyond the factual scenario in that case, and in none did the court extend its censure beyond public reproval of the government attorney. This is not to say that the court is without power to do so; in the material misstatements case, the court noted that it had the authority to sanction the misconduct but

decided not to exercise [the court's] authority in this case. ... We do not wish to penalize the inexperienced author of the misstatements, beyond this public reprimand, in view of the factual complexity of the case and the failure of the U.S. A ttorney's O ffice adequately to involve trial counsel in the supervision of the case on appeal. For the future, the U.S. A ttorney is on notice of the problem, and like any lawyer misleading $_{23}$ the court, henceforth may expect to face the full extent of our sanction power.

In light of warnings such as these, it is difficult to determine the level of conduct by a government attorney in a criminal case that would be considered beyond the pale and, on such an occasion, what the repercussions would be. A part from public censure in an opinion, the court could theoretically levy costs or attorneys' fees on the government, but this would prove unworkable in the many criminal cases in which the conviction is ultimately affirmed or in which the defense attorney is paid with public funds. ${ }^{24}$ (A nd, of course, prosecutors enjoy broad immunity from civil suits for any actions taken in the performance of their prosecutorial duties. ${ }^{25}$ ) The lawyer's malfeasance could, of

22. See, e.g., Brady v. M aryland, 373 U .S. 83 (1963) (holding that the prosecution must disclose material exculpatory evidence on request of defendant); FED R. CR IM P. 16 (listing evidence that must be disclosed to defendant).

23. Williams, 952 F.2d at 422.

24. In the last session of Congress, however, an appropriations rider was added to H.R . 2267 that allows courts, upon a criminal defendant's request, to order the government to pay attorneys' fees and costs if the defendant is acquitted and the prosecution found to be "vexatious, frivolous, or in bad faith," so long as the defendant was not represented by a public defender. The bill, which was adamantly opposed by D OJ, was enacted into law on N ovember 26, 1997. See D epartments of Commerce, J ustice, and State, The Judiciary and R elated A gencies A ppropriations A ct, Pub. L. N o. 105-119, tit. 6, $\S 617,111$ Stat. 2440, 2519 (1997). Similarly, in the civil arena, the E qual A ccess to Justice A ct, 28 U.S.C. $\S 2412$ (1994), awards attorneys' fees to a private party who prevails against the government and who can show that the government's position was not "substantially justified." Id. § 2412(d)(1)(A).

25. See, e.g., M oore v. Valder, 65 F.3d 189 (D.C. Cir. 1995), cert. denied, 117 S. Ct. 75 (1996). 
course, be referred to the local bar's disciplinary committee or to his supervisors at the U.S. A ttorney's O ffice or DOJ for the appropriate disciplinary action. ${ }^{26}$ In almost all cases, however, the court relies on public reproval to deter repetitions, and I am not aware of any case in recent memory in which our court has sanctioned a government attorney. ${ }^{27}$

To balance these public admonitions, the court does recognize when a government attorney performs up to snuff in a criminal case and shoulders the government's burden to ensure that justice is done. This burden includes, most notably, the disclosure of exculpatory evidence ${ }^{28}$ as well as the identification of errors that the trial judge may have made in applying the complex federal Sentencing G uidelines, even when those errors accrue to the advantage of the government. $^{29}$ Thus, in a recent case concerning a conviction for drug trafficking, the court commended the government attorney for bringing to the court's attention the fact that the defendant could not be convicted of both "distribution" and "distribution near a school" under the same facts and therefore that one conviction must be vacated. ${ }^{30} \mathrm{H}$ ad the shoe been on the other foot, there would, of course, have been no similar obligation on the part of defense counsel to alert the court to the fact that the government had missed an opportunity to seek an increase in the defendant's sentence.

A Ithough most of the remonstrances by judges of government lawyers tend to occur in criminal cases, where emotions run high and tempers occasionally flare, government lawyers may fail to meet their "higher standard" in civil cases as well. Perhaps the most notable example occurred in 1992, when then-Chief J udge M ikva, writing for the court, delivered a searing manifesto to a Federal E nergy R egulatory Commission ("FE R C") lawyer who had continued to press an appeal even though the case had become moot:

Ordinarily, we would handle such a manner in an unpublished order. We write, however, to express our displeasure with FER C counsel's failure to take easy and obvious steps to avoid needless litigation. ... M any lawyers would have seen the possibility of settlement as soon as FERC issued its open access order, mooting the present challenge.... Despite the benefits of settlement and the pointlessness of proceeding, FERC's counsel did not try to contact opposing counsel to explore whether vacating the [challenged] orders would resolve the case; nor did FERC's counsel recommend that the Commission file a motion to have this court remand the orders so that FER C

26. The D epartment of J ustice does not recognize the total authority of state and local bars to discipline its lawyers, especially where local rules forbid conduct of which the D epartment approves, such as contacting a witness directly rather than through her lawyer. See Letter, supra note 9, at 1302-04. The Eighth Circuit recently invalidated the regulation that authorized such ex parte contacts, holding that it could not supersede local rules to the contrary. See U nited States v. M cD onnell D ouglas Corp., 132 F.3d 1252 (8th Cir. 1998) (invalidating 28 C.F.R. § 77.10(a)).

27. Sanctions against government attorneys are not, however, unheard of in the district courts. See, e.g., A ssociation of A m. Physicians \& Surgeons v. Clinton, 989 F. Supp. 8 (D .D .C. 1997).

28. This disclosure is mandated by Brady. See B rady v. M aryland, 373 U .S. 83 (1963); see also supra note 22 and accompanying text.

29. Similarly, the Solicitor General, when arguing a criminal matter before the U.S. Supreme Court, is obligated to "confess error" by bringing to the Court's attention any fundamental errors that have occurred with respect to a federal criminal conviction. See, e.g., D rew S. Days, The Interests of the U nited States, the Solicitor G eneral and Individual Rights, 41 ST. L O UIS U . L.J . 1, 4 (1996).

30. See U nited States v. E dmonds, 69 F.3d 1172, 1178 n.6 (D.C. Cir. 1995). 
could vacate them unilaterally. FERC's counsel did not even disclose in the brief he drafted and filed with this court the Commission's position on vacating the challenged orders, leaving the impression that the Commission might oppose vacating them.

The court then made clear that it was, as FERC's counsel complained at oral argument, holding government lawyers to a different standard:

The notion that government lawyers have obligations beyond those of private lawyers did not originate in oral argument in this case. A government lawyer "is the representative not of an ordinary party to a controversy," the Supreme Court said long ago in a statement chiseled on the walls of the Justice Department, "but of a sovereignty whose obligation ... is not that it shall win a case, but that justice shall be done." The Supreme Court was speaking of government prosecutors [in that case], but no one, to our knowledge (at least prior to oral argument), has suggested that the principal does not apply with equal force to the government's civil lawyers. ...

We stress, to conclude, that we are concerned not so much with the failings of FER C's counsel in this case, but with the underlying view of a government lawyer's responsibilities that counsel revealed at oral argument. We find it astonishing that an attorney for a federal administrative agency could so unblushingly deny that a government lawyer has obligations that might sometimes trump the desire to pound an opponent into submission.

A s in the criminal arena, warnings such as these are more frequent than sanctions, ${ }^{33}$ leaving government attorneys somewhat in the dark about the limits of zealous advocacy. ${ }^{34}$ L itigating strategies are often complicated, moreover, by unsettled doctrines that prove difficult for any lawyer to navigate. Judges sometimes criticize government lawyers for asserting various technical defenses-standing, ripeness, finality, failure to exhaust administrative remedies, nonjusticiability - in an attempt to avoid proceeding to the merits of a case. ${ }^{35}$ But determining what may or may not be an appropriate threshold objection is not al ways crystalline, as one government lawyer has noted:

$M$ any federal judges seem to assume that the Department of J ustice automatically raises these arguments without proper reflection on their applicability and force in the context of a particular case. A lthough reflexive argument along these lines plainly does occur in some instances, much of the responsibility for the problem lies with the judges. M ost of these threshold defenses are judge-made and very difficult to apply. I defy anyone to examine the Supreme Court's decisions on standing over the past twenty-five years and to reconcile them and discern from them clear rules that can be applied to the wide variety of cases that arise. Trying to fit those Supreme Court

31. Freeport-M cM oR an Oil \& Gas Co. v. FE R C, 962 F.2d 45, $46-47$ (D.C. Cir. 1992).

32. Id. at $47-48$.

33. See, e.g., M ississippi River Transmission Corp. v. FER C, 969 F.2d 1215, 1217 n.2 (D.C. Cir. 1992) (expressing "extreme displeasure over FER C's tactics" and warning that "[a]ny repeat performance will be subject to sanctions").

34. Here, too, however, the court recognizes professional conduct. See, e.g., O din v. U nited States, 656 F.2d 798, 803 n.22 (D.C. Cir. 1981) ("We commend the government for the non-hypertechnical attitude it has taken [in its brief] towards this regulation, and for its willingness to see that justice is done.").

35. In a recent year, the government raised such defenses in $51 \%$ of administrative agency appeals. See Patricia M. Wald, Judicial Review in M idpassage: The Uneasy Partnership B etween Courts and A gencies Plays on, 32 TU LSA L.J . 221, 248 (1996). E fforts to secure dismissals were successful in $28 \%$ of these cases. See id. at 256. 
precedents with the widely vary only aggravates the difficulty.

While one judge is chastising a government attorney for raising these defenses, another is criticizing her for not doing so. O n one occasion, a panel of our court required a submission to the court, signed by the A ssistant A ttorney G eneral in charge of the division, setting out the division's policy about raising standing in all cases in which it could reasonably be argued. ${ }^{37}$ A s long as that point of view is represented on the court, it may be asking too much of government lawyers to make critical judgments about whether prudential defenses can be waived in furtherance of a debate on the substance of the law. The everpresent risk that the parties will be required to go back to square one because such a step was missed, with the attendant waste of the court's time as well as the parties', is not conducive to a freely discriminating choice about when to use or eschew jurisdictional objections, prudential or otherwise.

So perhaps in situations in which the government enjoys no particular advantage, it is a bit unfair to require more of the government lawyer simply because he or she represents "the people." ${ }^{38}$ This argument is weaker, however, when the case concerns an area that should be within the government lawyer's particular realm of knowledge. For example, courts are often frustrated when government counsel fail to inform them of new developments within the agency that might bear on the issue at hand. In one case, when neither the government lawyer nor the petitioner alerted the court to a revised FERC policy that put the order under review in question, the court devoted only a one-sentence footnote to admonishing the petitioner ${ }^{39}$ but a full paragraph to criticizing government counsel:

[W ]e are constrained to express our dismay with the Commission's failure to mention the revision of its capacity-brokering policy in its brief to the court. Counsel for FERC acknowledged the change only when directly confronted with the pertinent

FERC decisions at oral argument. We expect more from Government counsel. When an agency changes a policy or rule underlying a decision pending review, the agency should immediately inform the court and should either move on its own for a remand ${ }_{46}$ explain how its decision can be sustained independently of the policy in question.

In another case, the court reproved the government for not informing it until appeal that a new Medicare form would soon be implemented that would likely remedy the deficiencies in the challenged form:

We previously have emphasized that counsel are required to inform the courts of outside developments that might affect the outcome of litigation. A nd counsel for the government, no less than their colleagues in the private sector, are bound by the same

36. L etter, supra note 9 , at 1310-11 (footnote omitted).

37. See Supplemental Brief for the Federal A ppellees, National Mining A ss'n v. U nited States D ep't of I nterior, 70 F.3d 1345 (D.C.Cir. 1995) (N os. 94-5353, 94-5388, 95-5028).

38. O ne commentator has suggested that, in fact, the ethical codes "draw no distinctions between the duty of the government lawyer and the duty of the private lawyer to defend a civil case zealously." L anctot, supra note 13 , at 958.

39. See Panhandle E astern Pipe Line Co. v. FER C, 890 F.2d 435, 439 n.11 (D.C. Cir. 1989).

40. Id. at 439 (citation omitted). 
obligations to the court. There is, indeed, much to suggest that government counsel have a higher duty to uphold because their client is not only the agency they represent but also the public at large.

D espite this transgression, which "in a traditional case between two private parties... would foreclose [the party who failed to raise a relevant development] from relying on that change in circumstance during the remainder of the litigation," ${ }^{42}$ the court agreed to consider the new form, citing the "different ground rules" that apply when public policy is at stake. The lesson to be learned is that although government counsel may receive the brunt of the court's ire for failing to tell the court of new developments, ultimately they may also pay a lesser price because of the public policy dangers in ignoring these developments, whenever revealed.

It is indeed the public policy implications of the issues government counsel litigate that often lead a court to expect a wider perspective about a particular case from a government attorney than from a private attorney. A government attorney arguing before us can anticipate that she will be peppered with questions such as "W hy is the government doing this?"; "D oesn't the government care about the consequences?"; and "W hat is the government's interest in expending taxpayers' money on this case?" Naturally, there is no similar inquiry directed at private counsel; we know they are there to advance singlemindedly their client's interests, which are usually monetary in nature. But a sense lingers in the minds of some judges that the government's objectives in individual cases need to be probed to protect against the occasional abuse of government power. We expect government lawyers to be attentive to the implications that a case will have on future cases and on the development of the law, ${ }^{43}$ whereas we expect that a private lawyer will simply "win this day and let tomorrow take care of itself." ${ }^{44}$ The reverberations of our decision will likely be felt beyond the agency that is a party to the case, and so we feel the need to be informed of likely changes to relevant policies as a result of our holding. Thus, government lawyers can anticipate questions about what effect this holding may have in a variety of similar or even not-so-similar settings, even though they may understandably be reluctant to answer them for fear of revealing litigation or settlement strategies in other cases.

41. Gray Panthers v. Schweiker, 716 F.2d 23, 33 (D.C. Cir. 1983) (citation omitted); see also D ouglas v. D onovan, 704 F.2d 1276, 1279 (D.C. Cir. 1983) (stating that government attorneys "have special responsibilities to both [the] court and the public at large").

42. G ray Panthers, 716 F.2d at 33 .

43. See D ays, supra note 29 , at 3 :

A s a government lawyer, speaking for the Justice Department and the U nited States of A merica, one was expected to approach litigation with a bit more reserve and to advance one's arguments in the knowledge that their impact would undoubtedly reach beyond one case and one court to the entire federal judicial system.

44. See, e.g., Pilon v. U nited States D ep't of J ustice, 73 F.3d 1111, 1122 (D.C. Cir. 1996) (stating that D OJ 's narrow interpretation of prohibited "disclosure" in the instant case "would completely contravene the Privacy A ct's basic goals" and make it "an easy tool for manipulating and circumventing the Privacy A ct's limited exceptions to the bar against disclosure"). 
A t first glance, this might seem like an attempt by the federal courts to inject themselves into the public policy debate, a role some see as properly reserved for the elected branches. $Y$ et it is nearly impossible to guarantee the fidelity of Congress's intent in drafting statutes and to defer to agencies' reasonable interpretations of those statutes ${ }^{45}$ without engaging in some discussion of the policy behind the statute in question, including the projected results of the particular interpretation of that congressional policy adopted by the agency. Similarly, when a court reviews agency action under the A dministrative Procedure A ct, the court's decision comes down to whether that action was "arbitrary and capricious" - in other words, whether the action was reasonable. ${ }^{46}$ So while courts are told not to second-guess agency policymaking, we need an understanding of how the challenged action fits into the overall regulatory scheme and into the agency's larger policy perspective in order to evaluate its rationality. The government lawyer should be prepared to aid the court in that endeavor.

In addition, because the court views the government lawyer as the spokesperson for an institution that is often a repeat player, it not only feels free to question her about how that institution works but also to employ her as a conduit to carry messages back to the agency regarding its litigating practices. These judicial "observations" are occasionally set out in the court's opinion ${ }^{47}$ but are more often offered informally at oral argument (such as "H aven't we seen enough of this so-called expert witness?" $\left.{ }^{48}\right)$. Technically, if the practice is not reversible error, it is not our concern, ${ }^{49}$ yet the continual engagement of courts and government counsel makes such a dialogue almost inevitable. There are, of course, other fora for such exchanges, but none so likely to command the government's attention as an observation delivered during oral argument.

It seems clear, then, that courts hold government lawyers to something of a higher standard, even if how that standard is defined remains amorphous. O ne government attorney, however, has taken issue with the stricter approach, arguing that, if anything, the federal courts, and the D.C. Circuit in particular, should be more deferential to government lawyers in such matters as extending deadlines or granting petitions for rehearing and rehearing en banc. The gov-

45. See Chevron U .S.A. Inc. v. Natural R esources D efense Council, Inc., 467 U .S. 837 (1984).

46. See A rent v. Shalala, 70 F.3d 610 (D.C. Cir. 1995), for conflicting judicial views of the overlap between Chevron's Step 2 and arbitrary and capricious review under the A dministrative Procedure A ct. See also R onald M. Levin, The A natomy of Chevron: Step Two Reconsidered, 72 CHI.-K ENT L. REV. 1253 (1997).

47. See, e.g., U nited States v. Smart, 98 F.3d 1379, 1389 n.8 (D.C. Cir. 1996), cert. denied, 117 S. Ct. 1271 (1997) (stating that the court was "comforted to learn from government counsel at argument that the government no longer engages in posing ... mirroring hypothetical questions to its experts at trial. We are thus confident this case represents the end of the line on this problematic practice").

48. A fter skeptical questions from several panels, the court was informed at one oral argument that a government expert in the modus operandi of the drug trade, who figured prominently in at least 38 appeals in five years, had been "retired" from his expert witness status.

49. There is a doctrine of supervisory jurisdiction of appellate courts over the administration of criminal justice in the federal district courts, but its reach over officials of another branch is problematic. See, e.g., U nited States v. Cicero, 22 F.3d 1156, 1160 n.5 (D.C. Cir. 1994). 
ernment lawyer, he argues, is different from other counsel in that he more carefully reviews such litigating decisions and makes such requests only when it is deemed prudent or necessary, such as when additional time is needed to obtain authorization to proceed from a high-level officer. ${ }^{50}$ A lthough he acknowledges that "[j]udicial recognition of the substantial distinction between government attorneys and private practitioners should not lead to an inappropriate and potentially detrimental intimacy between the Judicial and Executive Branches," he argues in favor of some official recognition of the difference, leaving the "appropriate limits to the functional use of that distinction" to be "developed over time."

I admit to being a skeptic about any articulated presumption or privilege that favors the government in litigation. ${ }^{52}$ It is not only the slippery slope I fear from the first official acknowledgment that government lawyers are somehow "special," but also a mindset that might detract from the court's ever-present duty vigilantly to protect individual citizens from governmental transgressions. In fact, our court has had an enlightening experience when declining to create an exception for the government. In 1987, we began a modest appellate settlement program aimed at those cases in which no unsettled principles of law were involved and in which it appeared that the stakes simply did not justify the time and expense that full-press consideration by the court would entail. U nder the program, cases selected by the court's staff counsel pursuant to specific criteria would be assigned to an experienced lawyer-mediator who would conduct one mandatory mediation session, with subsequent sessions held at the option of the parties. ${ }^{53}$ DOJ was initially pessimistic that any of its cases on appeal would be appropriate for mediation and at one point asked to be exempted completely from the program. M ediators, for their part, reported that government lawyers typically were unhelpful in settling cases because they required approval from their superiors in the DOJ, which was often long in coming.

These attitudes changed, however, once one of our judges became Solicitor General and widely endorsed the program inside DOJ and with U.S. A ttorneys. The court worked out an arrangement with DOJ whereby persons with authority to settle cases would be available by phone to the government lawyer if settlement looked imminent. In addition, the court authorized the mediators, in their discretion, to request that agency representatives attend the mediation sessions if it appeared that it was the lawyer - and not the agency-who was resistant to settlement and to communicate offers directly to those representatives (with prior notice to government counsel). A s a result, the District of Columbia and federal governments are now involved in more than one-third of all mediated cases and are able to reach settlement in roughly one-third of D is-

50. See L etter, supra note 9 , at 1305.

51. Id. at 1307.

52. In fact, our court does allow a longer period after entry of judgment in which to file an en banc petition in a case involving the government ( 45 days) than when only private parties are involved ( 30 days). See D.C.CIR.R. 35.

53. Seeid. at app. III. 
trict cases and thirty percent of federal cases referred to the program. ${ }^{54} \mathrm{M}$ oreover, alternative dispute resolution ("ADR") has, of late, become a muchtouted approach to litigation inside government agencies. ${ }^{55}$ It will be interesting to see whether judges, through the review of settlements obtained by agency A D R programs, impose any "higher standards" on government counsel conducting settlement negotiations than they do on private parties. ${ }^{56}$

III

\section{The Government La Wyer in Court: Some Suggestions}

The courts have offered little by way of concrete suggestions as to what is included in the "higher standard" expected from government counsel. I offer for incorporation into that "higher standard" to which judges refer so often and so vaguely the following five "high Cs": competence, candor, credibility, civility, and consistency.

\section{A. Competence}

On the whole, judges expect a level of competence from government attorneys- even new and inexperienced ones-that we do not expect from private counsel. We have come to wince at the misspellings and typographical errors, the punctuation mistakes and gaps in logic, and the omitted precedent that appear with lamentable frequency in the product of private attorneys, but we become downright agitated when we see the same errors in the government's work. While we recognize that private firms range in size from the one person shop to the multi-hundred lawyer firm, we view the U S. government- of which there is only one-as a large organization with the financial and intellectual resources to train its lawyers before it sends them to court. We expect agency attorneys to be acquainted with relevant precedent and current developments and to lend the court the benefit of their experience in litigating similar cases. B ecause so many agencies are repeat players in our court, their lawyers quickly develop reputations- on either end of the spectrum - that can subtly affect the court's attitude toward their clients if such standards are not met.

\section{B. Candor}

Of course, all counsel should be honest and truthful in their dealings with the court. Realistically, however, courts know that while private counsel must answer direct questions truthfully, they need not voluntarily disclose everything about their client's motivations or plans. The government lawyer, by contrast,

54. See M emorandum from N ancy Stanley, A D R Program D irector, to Patricia M. Wald (Nov. 13, 1997) (on file with author); see also Patricia M. W ald, ". . . D octor, L awyer, M erchant, Chief", 60 G EO. WA SH. L. REV. 1127, 1135-36 (1992).

55. See Patricia M. Wald, A DR and the Courts: A n U pdate, 1997 D U KE L.J . 1445.

56. See, e.g., Cole v. Burns Int'l Sec. Servs., 105 F.3d 1465, 1467 (D.C. Cir. 1997) (setting forth standards for safeguarding employees' statutory rights in review of mandatory private arbitration agreements). 
is seen as having a duty to disclose to the court impending developments at the agency level-at least those that have moved beyond the mere discussion stage- that might signal a new policy direction or, in some other way, change the significance of the issue in dispute. A dmittedly, government counsel must tread carefully: He cannot disclose internal deliberations- he may not even have the authority to discuss alternative factual scenarios-but he cannot ignore the court's questions. To some extent, he is protected by the post hoc rationalization rule, which permits the court to consider only the reasons given by the agency for its actions and not ones proffered by counsel in the course of litigation. $^{57}$ B ut the court's cognizance of this rule is not likely to preclude its questions regarding the agency's overarching policy. Government lawyers would do well to anticipate such questions and obtain whatever authority they need from the agency to answer them in court.

Some of these questions are likely to concern the motivation for a particular government action. Courts are well aware that agencies are not apolitical outfits and that some of the positions taken have been influenced by political and administration intervention. ${ }^{58}$ Theoretically, if an agency has interpreted a statute reasonably and can point to evidence in the record to support its action, its motivation is irrelevant. Some decisions, however, are sufficiently tinged with obvious political considerations that a curious court is likely to dig beneath the surface. D uring the heyday of the Council on Competitiveness in the OM B, for example, agency rulemaking proposals were often sent back by the Council to the agencies for revision or alternatives more closely keyed to broader administrative goals. On some occasions, however, the rationale from the old rule had not been changed sufficiently to accommodate the new result, and in these cases, the court, not unexpectedly, was likely to ask government counsel what

57. See, e.g., National W ildlife Fed'n v. B rowner, 127 F.3d 1126, 1129 (D.C. Cir. 1997) (stating that agency litigating positions are not entitled to deference when they are merely counsel's post hoc rationalization for agency action).

58. See Neal D evins, U nitariness and Independence: Solicitor General Control over Independent A gency L itigation, 82 CA L. L. REV. 255, 284-85 (1994) (footnotes omitted), which describes the following interventions by the White $\mathrm{H}$ ouse in litigating positions taken by the Solicitor $\mathrm{G}$ eneral:

M odern accounts of such intervention include the following: Harry Truman's involvement in an amicus curiae filing in Shelly v. K raemer; D wight E isenhower's drafting of portions of the government's brief in Brown v. Board of Education; the Kennedy A dministration's order to A rchibald $\mathrm{Cox}$ to challenge private discrimination as unconstitutional state action; the Nixon A dministration's intervention in the Solicitor General's filing in the Pentagon Papers case and its involvement in school desegregation and antitrust matters; Gerald Ford's brokerage of a dispute between the FEC and the Solicitor G eneral in Buckley v. Valeo and Ford A dministration participation in school desegregation cases and D epartment of I nterior matters; the Carter W hite House's reversal of the Solicitor General's preliminary position in Bakke; the R eagan A dministration's reversal of the Solicitor G eneral's stated position in B ob J ones U niversity and its insistence that the Solicitor $\mathrm{G}$ eneral file an amicus brief calling for the overturning of Roe v. Wade in Thornburg v. College of O bstetricians; President Bush's order to the Solicitor General to reverse its position in the Supreme Court and support increased state aid to black public colleges to remedy discrimination; and President Clinton's indirect rebuke of the Solicitor G eneral's brief in K nox v. U nited States, a child pornography case. 
had happened to the rule along the route from the agency to the courthouse. ${ }^{59}$ In such cases, counsel must be candid about what is on the public record, but after that he is on his own, sometimes trapped between his duty to the court and his loyalty to his agency client. Courts understand his predicament, but this will not end their inquiry into the real reasons for the actions they are asked to affirm.

\section{Credibility}

Private lawyers are not required to believe in the causes of their clients; the same is true for government lawyers. M any young lawyers in both camps adopt a diffident approach toward defending positions in court with which they do not personally agree, justifying this attitude on the theory that everyone-including the government, which in most cases cannot turn to outside counsel-deserves to be represented; these lawyers believe it is up to the court to make the ultimate choices between the right and wrong result in particular cases. Still, a lawyer's alliance with or detachment from the position he takes may subtly affect the energy and enthusiasm with which he undertakes the assignment as well as how he projects the position in court. With changes in administrations, many government counsel understand that, at least in D O J lawyers are not required, at the peril of ending their careers, to represent government policy that collides with their most fundamental beliefs. ${ }^{60}$ (The "don't ask, don't tell" policy on gays in the military is one example, I am told, where lawyers sincerely opposed to the policy are excused from defending it.) This kind of leeway is wise policy for an agency; given that the government is a vast enterprise required to take on a multitude of subjects, the possibilities of both conflict and substitution are greater. ${ }^{61}$ It is also wise for government counsel to take their employer up on the offer: Their discomfort is often discernible to the court, and no government counsel should be asked to ignore deeply felt convictions (so long as he does not have too many).

D. Civility

The court expects (but does not always find) civility from its counsel toward one another. It is safe to say, however, that we are probably less tolerant of in-

The same kind of influence has, on occasion, been found to be exerted by an administration on D OJ attorneys in the lower courts. See, e.g., A ssociation of A m. Physicians \& Surgeons, Inc. v. Clinton, 989 F. Supp. 8, 16 (D.D.C. 1997) (describing pressure from White H ouse attorneys regarding D OJ's arguments before court).

59. See, e.g., N ew Y ork v. R eilly, 969 F.2d 1147, 1153 (D.C. Cir. 1992) (stating that E PA 's change of heart in not including a ban on burning of lead-acid vehicle batteries in its final rule after criticisms by $O M B$ and the Competitiveness $C$ ouncil not adequately explained).

60. See, e.g., L anctot, supra note 13, at 1003 n.218 (noting that D OJ attorneys strongly opposed to legality of drug testing on federal employees are ordinarily excused from defending the policy).

61. For a discussion of conscience conflicts for the government lawyer, see Patricia M. Wald, Whose Public Interest Is It A nyway?, 47 ME. L. REV . 3 (1995). See also Barbara A llen B abcock, Defending the Government: Justice and the Civil Division, 23 J. MARSHALL L. REV. 181 (1990) (describing conflict in roles government lawyers must play). 
civility, sarcasm, or belittling of an opponent when it comes from government attorneys than from private ones. This, I believe, is due to an underlying notion that we are all part of the same government; government attorneys' insensitivity reflects on the court as well. ${ }^{62}$

O ur concern for civility extends to signs of gender, ethnic, or racial bias, whether intentional or unintentional. A lthough thirty-seven percent of lawyers in the U.S. A ttorney's office in the D istrict of Columbia are women, ${ }^{63}$ some female attorneys throughout the government have expressed frustration with the gender-based behavior of their colleagues-for example, informal modes of address, frequent interruptions, and nonrecognition as attorneys-as well as the perceived limitations on their upward mobility due to a lack of mentors and exclusion from "macho" inner circles. Four of nine trial judges interviewed for the D.C. G ender, R ace, and E thnic B ias Task Force Project believed that race played a role in some prosecutors' charging decisions. ${ }^{64}$ Judges uniformly expect the government lawyer to keep in mind that his role as representative of the people should be all-inclusive. A s one former Solicitor G eneral has noted, the government lawyer and the courts are both employed by the same entity and thus have the same ultimate goals. A s a result, "the government lawyer must be more sensitive to the values on the other side of the lawsuit than is true of lawyers in general.... [T] ]he government's opponent... is also part of the public whose total interest the lawyer serves." ${ }^{\prime 5}$

\section{E. Consistency}

Consistency in government positions taken before the same court or different courts is one of the most vexing aspects of the relationship between judges and government lawyers. The problem arises in a variety of forms and contexts.

1. Consistency in the Same Case. In an era where the same basic factual dispute is capable of being legally conceptualized to give rise to several actions in several courts involving the same parties, the potential for inconsistent positions by government lawyers is a legitimate concern. I had one such experience in a Voting Rights Act case several years ago, where the

62. Cf. J UdiCial CONFERENCE OF THE U Nited StA TES, supra note 4, at Canon 3A (3):

A judge should be patient, dignified, respectful, and courteous to litigants, jurors, witnesses, lawyers, and others with whom the judge deals in an official capacity, and should require similar conduct of those subject to the judge's control, including lawyers to the extent consistent with their role in the adversary process.

63. See 1 United States Court of A ppeals (District of Columbia Circuit), Gender, RACE, AND ETHNIC BIASTASK ForCe PROJECT IN THE D.C. CIRCUIT IV, A-19 (1995) (1993-94 figures).

64. Seeid. at IV B-143.

65. Rex E. L ee, L awyering for the G overnment: Politics, Polemics and Principle, 47 OHIO ST. L.J. 595, 596 (1986). B ut see L anctot, supra note 13, at 994 (arguing that because the government lawyer represents the Executive B ranch, imposing on government lawyers a greater duty to the courts than on private attorneys "could present a serious interference with the separation of powers between the judicial and executive branches"). 
government's position under the Section 5 preclearance action appeared to me at least to be at odds with the position taken before another federal panel across the country considering the same factual scenario but under Section 2's anti-discrimination ban. It takes only one such experience, real or perceived, to make a judge wary. The problem of nationally coordinating legal arguments and positions is a formidable one and can, on occasion, be extremely frustrating for a government lawyer. N onetheless, judges do have, and should have, a right to expect consistency in the positions the government takes in different aspects of the same underlying case.

In one recent case, for instance, the government urged us to dismiss on jurisdictional grounds an affirmative suit brought by an individual under threat of a deportation order, assuring us that the plaintiff would have an opportunity through habeas proceedings to pursue her constitutional challenge. ${ }^{66}$ In a petition for rehearing, however, the petitioner claimed that the government's subsequent argument in another circuit, where an appeal from the original deportation order was pending, contradicted the government's "concessions" before our court by asserting that there was no forum in which her claims could be raised. (The government, naturally, denied this characterization of its actions.) The exchange underscores how important it is for government lawyers to ensure that they do not contradict themselves-or even subtly color the way in which they relate or challenge facts- before different courts embroiled in the same basic matter.

Within one court, two frequent sources of tension between government lawyers and judges arise. The first is irritating, although unavoidable: the occasional need for government lawyers to recede altogether from a position taken in a particular case because of a decision made by their superiors and confess error or withdraw a petition or defense altogether. Judges understand the dynamics of the situation but are not likely to be pleased about their wasted time and effort. The second lies in the very attenuated process the government goes through in deciding when to request an en banc hearing in our court, a process similar to the one it goes through when deciding to seek certiorari from the Supreme Court. When the government loses an appeal, especially after a fervent performance by counsel before the panel parading the horribles that will ensue if its position is not adopted, a dissenting judge who has embraced the government's cause will wait expectantly for the government to ask for rehearing en banc - often, as it turns out, in vain, "seduced and abandoned," as it were. ${ }^{67}$ of course, the government has many factors to weigh in deciding when to go up or even court-wide for another shot, but the dissenting judge who has gone out on a limb only to find the government did not really think it was a top priority after all is apt to feel frustrated and perhaps less willing to entertain such pleas in

66. See R amallo v. R eno, 114 F.3d 1210, 1214 (D.C. Cir. 1997) ("[A ]s the G overnment concedes, habeas review remains available"); A ppellee's Petition for R ehearing and Suggestion for R ehearing En B anc (under seal).

67. Cf. Wald, supra note 54 , at 1142 n.36 (describing practice of "concurring dissents" to encourage requests for en banc review). 
the next case. This conduct is particularly irksome when it appears that the decision to press forward has been made for reasons apart from the merits of the case itself. Most judges assume that the government must surely be beyond bringing cases on a "run it up the flagpole and see if it salutes" basis, and so it ought to be prepared to go forward unless it is truly convinced that the court that ruled against it was correct in the end. It may be, as my I rish grandmother used to say, that "he who fights and runs away, lives to fight another day," but the government lawyer should realize that there are casualties left behind.

2. Consistency in Similar Cases. In the same vein, we expect government lawyers to be reasonably consistent about the positions they take in similar cases. A private lawyer sometimes argues one meaning of a precedent one day and another meaning in a different case another day, but we would be outraged if the government did the same. ${ }^{68}$ This is the reason judges often ask government counsel if what they are arguing represents the policy of their office and whether it is being applied consistently to other litigants similarly situated. Sometimes the judge will ask for documentation that this is so; equal treatment of those subject to regulation ranks high on most judges' priority lists, and if it looks as though the agency is not evenly applying its policies across the board, these judges will want to know why not.

Similarly, we often chide the government lawyer who uses legislative history as an aid to statutory interpretation in one case where he is helped by such a technique but argues plain meaning in the next case with no reference to legislative history because that suits his ends. A Ithough the contours of the textualism debate are generally loose enough to permit the government to vary its mode of statutory interpretation between cases, ${ }^{69}$ our underlying belief is that the big law office of the U.S. government should keep its interpretations of cases and statutes consistent and should not tilt them in favor of the outcome desired in each case.

Consistency in the treatment of similar cases also brings us to the thorny topic of intracircuit nonacquiescence, that is, the refusal of an agency to honor relevant circuit precedent in subsequent cases before the agency. ${ }^{70}$ When an

68. Cf. Barry Tarlow, Rico R eport: Inconsistent A rguments in Successive Cases and the O bligations of D efense Lawyers-IS D efense Different?, THE CHAMPION, J an.-Feb. 1998, at 44 (considering whether defense lawyers have an ethical duty to avoid inconsistent arguments in successive cases).

69. The judges in the D.C. Circuit as well as the justices in the Supreme Court are a mix of textualists and interpretivists (those who use legislative history liberally to inform text). Perhaps because of my heavy exposure to the legislative process in my congressional liaison job, I favor the latter position. See, e.g., Patricia M. W ald, The Sizzling Sleeper: U se of L egislative H istory in Construing Statutes, 39 A M. U. L. REV. 277 (1990). I do concede, however, that it is tricky business for a government lawyer (or any lawyer) arguing an issue of statutory interpretation before a mixed court of textualists and interpretivists.

70. See $M$ atthew Diller \& Nancy M orawetz, Intracircuit N onacquiescence and the Breakdown of the Rule of L aw: A Response to Estreicher and Revesz, 99 Y A LE L.J . 801 (1991); Samuel Estreicher \& R ichard L. Revesz, Nonacquiescence by Federal A dministrative A gencies, 98 Y A LE L.J . 679 (1989); Samuel Figler, E xecutive A gency N onacquiescence to J udicial O pinions, 61 G E O. W A SH. L. REV. 1664 (1993). 
agency decides not to apply a circuit precedent to all similar cases arising in that circuit, each individual litigant affected has to file or defend another suit and the court has to render another judgment-the court, of course (barring en banc review), being controlled by its own precedent and thus compelled to rule in the same manner as it did in the earlier case.

A gencies typically justify intracircuit nonacquiescence by a perceived need to administer a statute uniformly throughout the nation and by a separation of powers theory that permits the executive branch to act independently so long as it is not in violation of the law. Critics of intracircuit nonacquiescence cite separation of powers to the opposite effect, emphasizing that, in the words of Marbury v. Madison, it is the duty of the courts "to say what the law is" ${ }^{71}$ and that it is the duty of agencies to follow that law. Critics also sometimes suggest that agencies may risk violating the $\mathrm{E}$ qual Protection Clause by applying the law in different ways to similarly situated litigants, with the result that a person's ability to take advantage of circuit precedent depends on her financial ability to appeal the agency's decision. Courts are understandably very hostile to intracircuit nonacquiescence, although, in the words of one commentator, they "respond[] in typical fashion by delivering a scathing criticism of the practice but tak[e] no substantive action." ${ }^{72}$ (In 1983, the N inth Circuit declared the practice unconstitutional, but the Supreme Court ducked the question thanks to a congressional enactment that ended intracircuit nonacquiescence in Social Security A dministration cases. ${ }^{73}$ ) A government lawyer would be well advised to avoid, if he can possibly do so, arguing intracircuit nonacquiescence, which puts him in an adversarial position vis-à-vis the very court before which he is pleading. ${ }^{74}$

M ore frequently, however, agencies will engage in intercircuit nonacquiescence: They will follow circuit precedent for all appeals heard in that circuit but will not treat that precedent as authoritative in circuits that have previously ruled in the agency's favor or that have yet to rule on the issue. ${ }^{75}$ This practice has more to commend it. Most federal laws are national in scope; for some, challenges must be brought exclusively in one circuit but for many others (and for some enforcement proceedings), the initiator of the action may choose the forum. Thus the government may find itself in several circuits, simultaneously or seriatim, with different results in each case. Since the Supreme Court has

\footnotetext{
71. 5 U .S. 137,177 (1803).

72. Figler, supra note 70 , at 1665.

73. See L opez v. Heckler, 725 F.2d 1489 (9th Cir.), vacated on other grounds, 469 U .S. 1082 (1984).

74. A proposed Federal A gency Compliance Bill, H.R. 1544, 105th Cong. (1997), would make intracircuit nonacquiescence more difficult; it bars "unjustifiable" nonacquiescence unless the identity of the reviewing circuit is unclear, the government could not have sought review of the controlling decision, or the precedential value of the decision is questionable. The Judicial Conference endorses the bill; DOJ is opposed to it. See OFFICE OF LEGISLA TIVE A FFA IRS, A DMINISTRATIVE OFFICE OF THE U NiTEd StA TES COURTS, LE GISLA TIVE SURVEY, 105Th Cong. 37-38 (1997).

75. O ften, because of the choice of fora, an agency cannot predict where a particular appeal will be brought. See, e.g., Purolator A rmored, Inc. v. NLR B, 764 F.2d 1423 (11th Cir. 1985) (National Labor Relations B oard); Stieberger v. B owen, 801 F.2d 29 (2d Cir. 1986) (Social Security A dministration).
} 
the final judicial word on any issue of federal constitutional or statutory law, which may be long in coming, the government will not want to be bound by a preliminary negative result in a lower court unless it is convinced that the decision is right. So may the government seek, circuit by circuit, the result it desires on a particular issue, given that each circuit develops law independently? A nd when it confronts national or multistate organizations, may it commence a new suit in a more favorable circuit when an adverse decision involving the same opponent has already been rendered in one circuit?

The Supreme Court has spoken a few-but only a few-words on the subject. In U nited States v. M endoza, ${ }^{76}$ the Court held that the usual rules for collateral estoppel are not applicable to the government:

The conduct of government litigation in the courts of the $U$ nited States is sufficiently different from the conduct of private civil litigation in those courts so that what might otherwise be economy interests underlying a broad application of collateral_estoppel are outweighed by the constraints which particularly affect the G overnment.

In short, collateral estoppel may not be applied against the government if the parties are not the same. This inheres in the unique position of a government lawyer: While private litigants who do not appeal unfavorable rulings can be held to have waived their right to relitigate the issue, "the Solicitor G eneral considers a variety of factors, such as the limited resources of the government and the crowded dockets of the courts, before authorizing an appeal." 78 M endoza thus seems to give a green light to the government to litigate the same issue in different circuits so long as its opponent is different. ${ }^{79}$ But the government lawyer litigating an intercircuit nonacquiescence case must still tread carefully.

Johnson v. United States Railroad Retirement Board ${ }^{80}$ is a case in point. J ohnson concerned the eligibility of the wife of a deceased railroad worker for a spousal annuity. The B oard, resolving a conflict between the Social Security $A$ ct and the R ailroad R etirement A ct, held her ineligible as of the time her youngest child turned sixteen, rather than eighteen. Two prior circuits had disagreed with the Board's interpretation by the time that the case reached us, and we, likewise, ruled for the wife, noting that the Board had sought neither certiorari in either of the two prior decisions nor congressional clarification. We admonished the Board to change its nonacquiescence policy-which we, agreeing with a dissenting Board member, called "grossly unjust" and "a bold challenge to judicial authority," noting that it raised "serious statutory and constitutional questions" ${ }^{81}$ - in light of the three reversals. ${ }^{82}$

\footnotetext{
76. 464 U .S. 154 (1984).

77. Id. at 162-63.

78. Id. at 161 .

79. The Court in M endoza emphasized the usefulness of intercircuit dialogue before the Supreme Court decided a case, both as an indicator of the seriousness of the issue and as a source for refining its own rationale. It also mentioned the danger of "freezing" the first decision against an agency. Id. at 160.
}

80. 969 F.2d 1082 (D.C.Cir. 1992).

81. Id. at $1084,1090,1091$. 
In these types of cases, counsel in all probability has not determined agency policy, but he often bears the brunt in trying to defend it, a point courts would do well to keep in mind.

3. Consistency Within the G overnment I tself. G overnment, of course, is not a monolith. Different agencies have different missions and different degrees of accountability to the President and to congressional mandates. DOJ has labored long and not always successfully for centralization in the government's litigation and has issued Memoranda of Understanding to provide for consultation, negotiation, and occasionally co-counselship with agency lawyers in presenting appeals in court. But independent agencies, and even some departments, eager to control their own destiny, appeal to Congress and the courts for their own litigating authority, some successfully. ${ }^{83}$ The result is that, on many occasions, two government lawyers will come to court on opposite sides of a case $^{84}$ or the U nited States may take a position as amicus or intervenor that is inconsistent with that maintained by an agency party. In these cases, the court feels more at liberty to decide on its own where right and justice lie. Deference is diffused, and the job of the government's counselboth of them-is made proportionately more difficult.

O ur court is by now inured to cases in which the government is a house divided. Some statutory schemes are structured so as to make intragovernmental disputes inevitable. ${ }^{85}$ W e have for many years adjudicated disputes between the Independent Counsel and parts of the executive over subpoenaed material and privileges, $^{86}$ and Congress itself, through bodies such as the Office of Senate Legal Counsel, ${ }^{87}$ may appear on the opposite side of a case from the executive. In such cases, the government lawyer cannot expect quite the deference he gets when he represents a unified U nited States; in most instances, judges can be expected to depend more on their own independent grasp of the case than on any presumption in favor of either part of the government's interpretation.

82. The Federal A gency Compliance B ill, supra note 74 , also requires D OJ and agency officials to ensure that federal litigation is initiated, defended, or continued so as to avoid unnecessarily repetitive litigation when three or more judicial circuits have resolved an issue against the government's litigating position.

83. See, e.g., Mail O rder A ss'n of A merica v. U nited States Postal Serv., 986 F.2d 509 (D.C. Cir. 1993) (denying D OJ's challenge to U S. Postal Service's attempt to represent itself in appeal of Postal $\mathrm{R}$ ate Commission order).

84. See D evins, supra note 58 , at 313 ("Independent agencies and the D epartment of J ustice often air intragovernmental conflicts before lower federal courts of appeals."); id. at 315-16 (citing cases). The Supreme Court has recognized that such intragovernmental disputes may prevent a cognizable case or controversy. See, e.g., U nited States v. ICC, 337 U.S. 426 (1949) (involving D OJ challenge to ICC's rejection of U S. A rmy complaint against unreasonable railroad rates).

85. See, e.g., M artin v. OSH R C, 499 U S. 144 (1991) (reviewing court must defer to Secretary, not OSHRC, in interpretation of ambiguous D epartment of $L$ abor regulation in "split enforcement" statutory scheme for health or safety regulations).

86. See, e.g., In re B ruce R. Lindsey (G rand J ury T estimony), 148 F.3d 1100 (D.C. Cir. 1998); In re Sealed Case, 148 F.3d 1073 (D.C. Cir. 1998); In re Sealed Case, 121 F.3d 729 (D.C. Cir. 1997).

87. See 2 U.S.C. § 288 (1994). 
IV

CONCLUSION

While it is a proud boast of our judicial system that the government gets no better break in court than private counsel, there are, realistically, differences between the two. Judges, especially in specialized courts such as the D.C. Circuit, get to know government lawyers (as repeat players) better and to expect more of them by way of competence, candor, civility, credibility, and consistency. The result is often that judges come down harder on government lawyers when they deviate from professional norms or even the special norms judges have constructed for them. Strong advocacy by government lawyers of their agency clients is to be desired, but most judges want the government lawyer to consider the "public interest," ephemeral as that is, to be his phantom client as well.

G overnment lawyers are fortunate, in many respects: They argue cases of enormous importance with implications for a citizenry constituency far beyond the opposing party in the immediate case. For that privilege, they can anticipate being endlessly probed and queried about consistency in government enforcement and the real-world consequences of doctrinal theories and arguments. By and large that is as it should be.

The knotty problem of agency nonacquiescence continues to mar the judgegovernment lawyer relationship and needs to be focused upon in a nonpartisan way apart from the "crisis of the moment." O therwise, government lawyers must be reconciled to being held to a largely indefinable "higher standard" of conduct in the courtroom. (I have tried to give it some content but have no illusions that there are not hundreds of other variations on the theme.) Withal, I would be surprised if many government lawyers would trade places with their private counterparts-assuming economic factors are out of the picture and their legal philosophies are compatible with those of the administration in power. When the government lawyer rises to speak "for the U nited States," that is its own reward. 